\title{
Effect of $\mathrm{Cr}$ and $\mathrm{Ni}$ on diffusion bonding of $\mathrm{Fe}_{3} \mathrm{Al}$ with steel
}

\author{
WANG JUAN ${ }^{\dagger}$ LI YAJIANG* $*^{\dagger}$ and MA HAIJUN ${ }^{\dagger}$ \\ *Key Lab of Liquid Structure and Heredity of Materials, Ministry of Education, Shandong University, Jinan 250061, \\ China \\ ${ }^{\dagger}$ National Key Lab of Advanced Bonding Production Technology, Harbin Institute of Technology, Harbin 150001, \\ China
}

MS received 17 August 2004

\begin{abstract}
Microstructure at the diffusion bonding interface between $\mathrm{Fe}_{3} \mathrm{Al}$ and steel including Q235 low carbon steel and Cr18-Ni8 stainless steel was analysed and compared by means of scanning electron microscopy and transmission electron microscopy. The effect of $\mathrm{Cr}$ and $\mathrm{Ni}$ on microstructure at the $\mathrm{Fe} \mathrm{Al}_{3} \mathrm{Al} / \mathrm{steel}$ diffusion bonding interface was discussed. The experimental results indicate that it is favourable for the diffusion of $\mathrm{Cr}$ and $\mathrm{Ni}$ at the interface to accelerate combination of $\mathrm{Fe}_{3} \mathrm{Al}$ and steel during bonding. Therefore, the width of $\mathrm{Fe}_{3} \mathrm{Al} / \mathrm{Cr18}-\mathrm{Ni8}$ interface transition zone is more than that of $\mathrm{Fe}_{3} \mathrm{Al} / \mathrm{Q235}$. And $\mathrm{Fe}_{3} \mathrm{Al}$ dislocation couples with different distances, even dislocation net occurs at the $\mathrm{Fe}_{3} \mathrm{Al} / \mathrm{Cr} 18-\mathrm{Ni8}$ interface because of the dispersive distribution of $\mathrm{Cr}$ and $\mathrm{Ni}$ in $\mathrm{Fe}_{3} \mathrm{Al}$ phase.
\end{abstract}

Keywords. $\mathrm{Cr} ; \mathrm{Ni} ; \mathrm{Fe}_{3} \mathrm{Al} /$ steel interface; diffusion bonding.

\section{Introduction}

$\mathrm{Fe}_{3} \mathrm{Al}$ intermetallic is a candidate material for structural application in many industrial fields such as aviation, automobile and energy transition system because of its excellent strength at elevated temperature, resistance to oxidation and low cost (Mckamey et al 1991; Sun et al 2001). The weldability of $\mathrm{Fe}_{3} \mathrm{Al}$ intermetallic has also drawn wide attention of the research community. The welding processes used are gas tungsten arc welding, electron beam welding and vacuum diffusion bonding (David and Zacharia 1993; Gao et al 2000; Li and Wang 2003). The results indicate that only by choosing weld wire with the same chemical composition as the base metal and strictly controlling welding heat input, can weld crack be avoided when using gas tungsten arc welding. While using electron beam welding and vacuum diffusion bonding processes, weld crack can be effectively avoided because of the vacuum atmosphere in welding. In addition, the vacuum diffusion bonding of $\mathrm{Fe}_{3} \mathrm{Al}$ intermetallic with dissimilar materials has been studied (Wang et al 2001, 2003). But reports on the effect of alloying elements on diffusion bonding of $\mathrm{Fe}_{3} \mathrm{Al}$ with steel are few.

In this paper, microstructure at the diffusion bonding interface between $\mathrm{Fe}_{3} \mathrm{Al}$ and steel including Q235 low carbon steel and $\mathrm{Cr} 18-\mathrm{Ni} 8$ stainless steel was analysed and compared by means of SEM and TEM. The effect of $\mathrm{Cr}$ and $\mathrm{Ni}$ on microstructure at the $\mathrm{Fe}_{3} \mathrm{Al} /$ steel interface was discussed. The results indicate that it is possible to pro-

*Author for correspondence (yajli@ sdu.edu.cn) mote favourable microstructure at the $\mathrm{Fe}_{3} \mathrm{Al} /$ steel diffusion bonding interface.

\section{Experimental}

The base metals in the test are $\mathrm{Fe}_{3} \mathrm{Al}$ intermetallic, Q235 low carbon steel and $\mathrm{Cr} 18-\mathrm{Ni} 8$ stainless steel. The chemical composition of Q235 steel is (wt\%) C $0.14 \%$, Si $0.10 \%$, Mn $0.5 \%$, S $0.035 \%$, P $0.035 \%$ and Fe balance. The chemical composition and thermo-physical properties of $\mathrm{Fe}_{3} \mathrm{Al}$ and $\mathrm{Cr} 18-\mathrm{Ni} 8$ steel are listed in table 1.

Samples for diffusion bonding were prepared by grinding on sand paper, acetone cleaning, alcohol cleaning, water rinsing and drying. Diffusion bonding was conducted in vacuum chamber of Workhorse II equipment immediately after the above treatments. The diffusion bonding was carried out at $1333 \mathrm{~K}$ for $60 \mathrm{~min}$ with a pressure of $15 \mathrm{MPa}$ in a vacuum of $4.5 \times 10^{-5} \mathrm{~Pa}$. In the heating process, several holding temperature stages were included to promote uniformity of heat in the samples. The temperature of chamber is brought down to $373 \mathrm{~K}$ by water circulation and then it was cooled to room temperature within the furnace.

The samples of $\mathrm{Fe}_{3} \mathrm{Al} /$ steel joint were cut and etched with a solution of $75 \%$ hydrochloric acid and $25 \%$ nitric acid for metallographic observation. Microstructural characteristics and fine structures at the $\mathrm{Fe}_{3} \mathrm{Al} / \mathrm{Q} 235$ and $\mathrm{Fe}_{3} \mathrm{Al} / \mathrm{Cr} 18-\mathrm{Ni} 8$ interface were analysed by means of JXA-840 scanning electron microscope (SEM) and transmission electron microscope (TEM) with PV9900-H-8010 energy spectrum analysis system. 


\section{Results and discussion}

\subsection{Effect on microstructure}

Microstructure at the $\mathrm{Fe}_{3} \mathrm{Al}$ /steel diffusion bonding interface obtained under $1333 \mathrm{~K}$ for $60 \mathrm{~min}$ with a pressure of $15 \mathrm{MPa}$ is shown in figure 1 . It can be seen that there is obvious mutual diffusion and an interface transition zone is formed between $\mathrm{Fe}_{3} \mathrm{Al}$ and steel. Microstructure in the interface transition zone and on two sides of $\mathrm{Fe}_{3} \mathrm{Al}$ and steel is interlaced. The width of $\mathrm{Fe}_{3} \mathrm{Al} / \mathrm{Cr} 18-\mathrm{Ni} 8$ interface transition zone is $35 \mu \mathrm{m}$, which is more than that of $\mathrm{Fe}_{3} \mathrm{Al} / \mathrm{Q} 235$ interface transition zone $(29 \mu \mathrm{m})$ under the same bonding parameters $(1333 \mathrm{~K} \times 60 \mathrm{~min}, 15 \mathrm{MPa})$. This is because the diffusion of $\mathrm{Cr}$ and $\mathrm{Ni}$ from $\mathrm{Cr} 18-\mathrm{Ni} 8$ to $\mathrm{Fe}_{3} \mathrm{Al}$ can affect the dynamic balance at the $\mathrm{Fe}_{3} \mathrm{Al} /$ Cr18-Ni8 interface and accelerate the diffusion of $\mathrm{Al}$ towards the side of $\mathrm{Cr} 18-\mathrm{Ni} 8$ to improve the bonding between $\mathrm{Fe}_{3} \mathrm{Al}$ and $\mathrm{Cr} 18-\mathrm{Ni} 8$.

In addition, there are second phases with irregular shape distributed dispersively in the interface transition zone between $\mathrm{Fe}_{3} \mathrm{Al}$ and steel. The chemical composition of second phases was analysed by means of electron probe microanalysis (EPMA) and the results are listed in table 2.
$\mathrm{C}$ and $\mathrm{Cr}$ contents in the second phase of the $\mathrm{Fe}_{3} \mathrm{Al} /$ Q235 interface transition zone are more than that in the matrix and $\mathrm{Fe}$ and $\mathrm{Al}$ contents are less, while in the $\mathrm{Fe}_{3} \mathrm{Al} / \mathrm{Cr} 18-\mathrm{Ni} 8$ interface transition zone, $\mathrm{Cr}$ and $\mathrm{Ni}$ contents are more than that in the matrix and $\mathrm{Fe}$ and $\mathrm{Al}$ contents are also less. This is because of the insufficient time for $\mathrm{C}$ and $\mathrm{Cr}$ to diffuse fully in the $\mathrm{Fe}_{3} \mathrm{Al} / \mathrm{Q} 235$ interface transition zone during diffusion bonding. The second phase rich in $\mathrm{Cr}$ and $\mathrm{Ni}$ in the $\mathrm{Fe}_{3} \mathrm{Al} / \mathrm{Cr} 18-\mathrm{Ni} 8$ interface transition zone can restrain effectively $\mathrm{C}$ precipitation to avoid the formation of carbide.

\subsection{Effect on fine structure}

TEM morphology and electron diffraction pattern of $\mathrm{Fe}_{3} \mathrm{Al}$ in the $\mathrm{Fe}_{3} \mathrm{Al} / \mathrm{Q} 235$ interface transition zone are shown in figures $2 \mathrm{a}-\mathrm{c}$. The results from electron diffraction pattern and index schematic diagram indicate that $\mathrm{Fe}_{3} \mathrm{Al}$ formed in $\mathrm{Fe}_{3} \mathrm{Al} / \mathrm{Q} 235$ interface transition zone exhibits a superlattice. It can be seen from [110] orientation that fine structure of $\mathrm{Fe}_{3} \mathrm{Al}$ consists of dislocation walls which include several small regions. The production of $\mathrm{Fe}_{3} \mathrm{Al}$ dislocation walls is closely related to the

Table 1. Chemical composition and thermo-physical properties of $\mathrm{Fe}_{3} \mathrm{Al}$ and $\mathrm{Cr} 18-\mathrm{Ni} 8$ steel.

\begin{tabular}{|c|c|c|c|c|c|c|c|c|c|c|}
\hline \multicolumn{11}{|c|}{ Chemical compositions (wt $\%$ ) } \\
\hline Material & $\mathrm{Al}$ & $\mathrm{Cr}$ & $\mathrm{Nb}$ & $\mathrm{Ni}$ & $\mathrm{Zr}$ & B & $\mathrm{Ce}$ & S & $\mathrm{P}$ & $\mathrm{Fe}$ \\
\hline $\begin{array}{l}\mathrm{Fe}_{3} \mathrm{Al} \\
\mathrm{Cr} 18-\mathrm{Ni} 8\end{array}$ & $\begin{aligned} 16 \cdot 0 & \sim 17 \cdot 0 \\
& -\end{aligned}$ & $\begin{array}{c}2 \cdot 40 \sim 2 \cdot 55 \\
18 \cdot 21\end{array}$ & $\begin{aligned} 0.95 & \sim 0.98 \\
& -\end{aligned}$ & - & $\begin{aligned} 0.05 & \sim 0.15 \\
& -\end{aligned}$ & 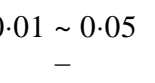 & $\begin{aligned} 0.05 & \sim 0 \cdot 15 \\
& -\end{aligned}$ & $\begin{array}{c}- \\
0.03\end{array}$ & $\begin{array}{c}- \\
0.03\end{array}$ & $\begin{array}{l}\text { Bal. } \\
\text { Bal. }\end{array}$ \\
\hline \multicolumn{11}{|c|}{ Thermo-physical properties } \\
\hline Material & Structure & $\begin{array}{l}\text { Order critical } \\
\text { temperature } \\
\text { (K) }\end{array}$ & $\begin{array}{l}\text { Young's } \\
\text { modulus } \\
(\mathrm{GPa})\end{array}$ & $\begin{array}{l}\text { Melting } \\
\text { point } \\
(\mathrm{K})\end{array}$ & $\begin{array}{l}\text { Coefficient of } \\
\text { thermal expansion } \\
\left(10^{-6} \cdot \mathrm{K}^{-1}\right)\end{array}$ & $\begin{array}{l}\text { Density } \\
\left(\mathrm{g} \cdot \mathrm{cm}^{-3}\right)\end{array}$ & $\begin{array}{c}\text { Tensile } \\
\text { strength } \\
(\mathrm{MPa})\end{array}$ & $\begin{array}{c}\text { Elongation } \\
(\%)\end{array}$ & \multicolumn{2}{|c|}{ Hardness } \\
\hline $\mathrm{Fe}_{3} \mathrm{Al}$ & $\mathrm{DO}_{3}$ & 813 & 140 & 1813 & $11 \cdot 5$ & $6 \cdot 72$ & 455 & 3 & \multirow{2}{*}{\multicolumn{2}{|c|}{$\begin{array}{r}\geq 29 \mathrm{HRC} \\
70 \mathrm{HRB}\end{array}$}} \\
\hline $\mathrm{Cr} 18-\mathrm{Ni} 8$ & - & - & - & - & $16 \cdot 7$ & 8.03 & 520 & 40 & & \\
\hline
\end{tabular}
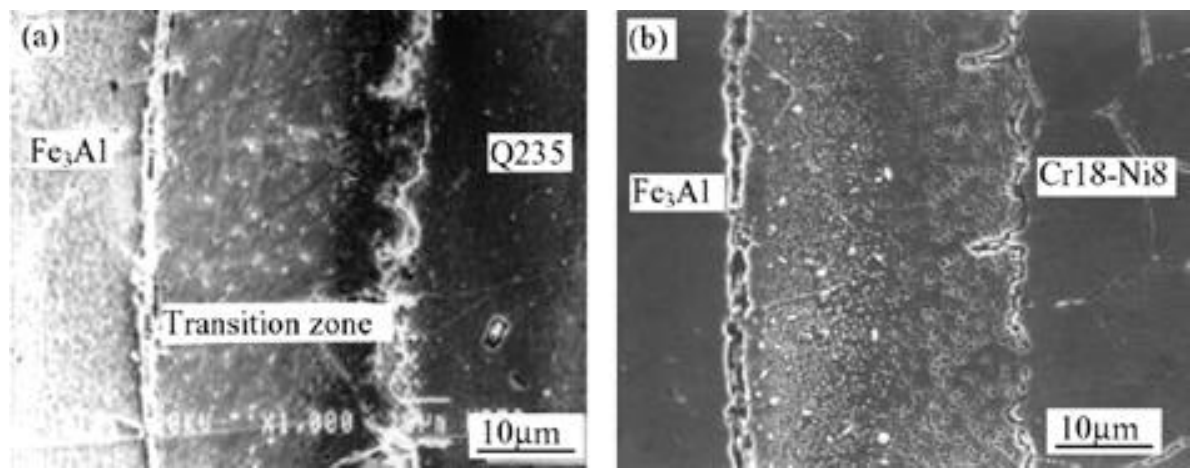

Figure 1. Microstructure at the $\mathrm{Fe}_{3} \mathrm{Al} /$ steel diffusion bonding interface: (a) $\mathrm{Fe}_{3} \mathrm{Al} / \mathrm{Q} 235$ and (b) $\mathrm{Fe}_{3} \mathrm{Al} / \mathrm{Cr} 18-\mathrm{Ni} 8$. 
motion of dislocations. The dislocation walls can affect dislocation glide and even microstructure at the $\mathrm{Fe}_{3} \mathrm{Al} /$ Q235 diffusion bonding interface.

TEM morphology, electron diffraction pattern and index schematic diagram of $\mathrm{Fe}_{3} \mathrm{Al}$ in the $\mathrm{Fe}_{3} \mathrm{Al} / \mathrm{Cr} 18-\mathrm{Ni} 8$ interface transition zone are shown in figures $3 \mathrm{a}-\mathrm{c}$. Dislocations with [001] orientation are distributed in couples and the spacing is small between the dislocation couples. This is because $\mathrm{Cr}$ and $\mathrm{Ni}$ diffused at the $\mathrm{Fe}_{3} \mathrm{Al} / \mathrm{Cr} 18-\mathrm{Ni} 8$ interface can hamper the superlattice dislocation motion in $\mathrm{Fe}_{3} \mathrm{Al}$. The external applied stress can make dislocations decompose into unit dislocations and they slide alternatively. In addition, $\mathrm{Cr}$ and $\mathrm{Ni}$ can decrease the antiphase boundary energy during the deformation of $\mathrm{Fe}_{3} \mathrm{Al}$ (Mckamey et al 1990; Yin et al 1996). This will cause an increase in the spacing between dislocation couples.
$\mathrm{Fe}_{3} \mathrm{Al}$ dislocations with [1 $\left.\overline{2} 2\right]$ orientation are mostly unpaired and they are tangled in some regions (figures $4 \mathrm{a}-\mathrm{c})$. This has resulted from the diffusion of $\mathrm{Cr}$ and $\mathrm{Ni}$ at the $\mathrm{Fe}_{3} \mathrm{Al} / \mathrm{Cr} 18-\mathrm{Ni} 8$ diffusion bonding interface. The diffused $\mathrm{Cr}$ and $\mathrm{Ni}$ can be precipitated in the second phase and distributed dispersively in $\mathrm{Fe}_{3} \mathrm{Al}$. When the individual dislocation moves to the second phase, continued glide is hampered and they form a dislocation net.

When the dislocation pairs with small spacing and dislocations in a network at the $\mathrm{Fe}_{3} \mathrm{Al} / \mathrm{Cr} 18-\mathrm{Ni} 8$ diffusion bonding interface move during the diffusion bonding, they restrict the smooth glide of each other. $\mathrm{Fe}_{3} \mathrm{Al}$ has these various dislocation features at the $\mathrm{Fe}_{3} \mathrm{Al} / \mathrm{Cr} 18-\mathrm{Ni} 8$ diffusion bonding interface because of $\mathrm{Cr}$ and $\mathrm{Ni}$ diffusion which are favourable for improving the strength of the diffusion bonding interface.

Table 2. EPMA analysis on second phase in the transition zone between $\mathrm{Fe}_{3} \mathrm{Al}$ and steel $(\%)$.

\begin{tabular}{|c|c|c|c|c|c|c|c|c|}
\hline Position & No. & $\mathrm{Fe}$ & $\mathrm{Al}$ & $\mathrm{C}$ & $\mathrm{Cr}$ & $\mathrm{Nb}$ & $\mathrm{Zr}$ & $\mathrm{Ni}$ \\
\hline \multirow[t]{4}{*}{$\mathrm{Fe}_{3} \mathrm{Al}$ matrix } & 1 & $82 \cdot 60$ & $16 \cdot 62$ & $0 \cdot 14$ & 0.52 & $0 \cdot 05$ & 0.07 & - \\
\hline & 2 & $82 \cdot 80$ & $16 \cdot 40$ & $0 \cdot 13$ & 0.49 & 0.03 & 0.05 & - \\
\hline & 3 & $81 \cdot 91$ & $17 \cdot 10$ & 0.13 & $0 \cdot 51$ & 0.03 & $0 \cdot 02$ & - \\
\hline & 4 & $82 \cdot 21$ & $16 \cdot 90$ & $0 \cdot 13$ & 0.54 & $0 \cdot 01$ & $0 \cdot 01$ & - \\
\hline \multirow{4}{*}{$\mathrm{Fe}_{3} \mathrm{Al} / \mathrm{Q} 235$} & 1 & 81.69 & $16 \cdot 35$ & 0.55 & $1 \cdot 18$ & $0 \cdot 01$ & $0 \cdot 02$ & - \\
\hline & 2 & 81.94 & $15 \cdot 90$ & 0.51 & $1 \cdot 28$ & 0.03 & 0.04 & - \\
\hline & 3 & $82 \cdot 54$ & $15 \cdot 47$ & 0.40 & $1 \cdot 32$ & 0.04 & 0.03 & - \\
\hline & 4 & $81 \cdot 89$ & $16 \cdot 23$ & $0 \cdot 22$ & $1 \cdot 26$ & $0 \cdot 04$ & $0 \cdot 06$ & - \\
\hline \multirow{4}{*}{$\mathrm{Fe}_{3} \mathrm{Al} / \mathrm{Cr} 18-\mathrm{Ni} 8$} & 1 & $71 \cdot 8$ & $12 \cdot 5$ & - & $8 \cdot 9$ & - & - & $4 \cdot 4$ \\
\hline & 2 & $72 \cdot 3$ & $9 \cdot 5$ & - & $13 \cdot 2$ & - & - & $4 \cdot 5$ \\
\hline & 3 & 73.9 & $2 \cdot 5$ & - & $17 \cdot 2$ & - & - & $8 \cdot 0$ \\
\hline & 4 & $71 \cdot 8$ & $8 \cdot 3$ & - & $14 \cdot 3$ & - & - & $5 \cdot 6$ \\
\hline
\end{tabular}
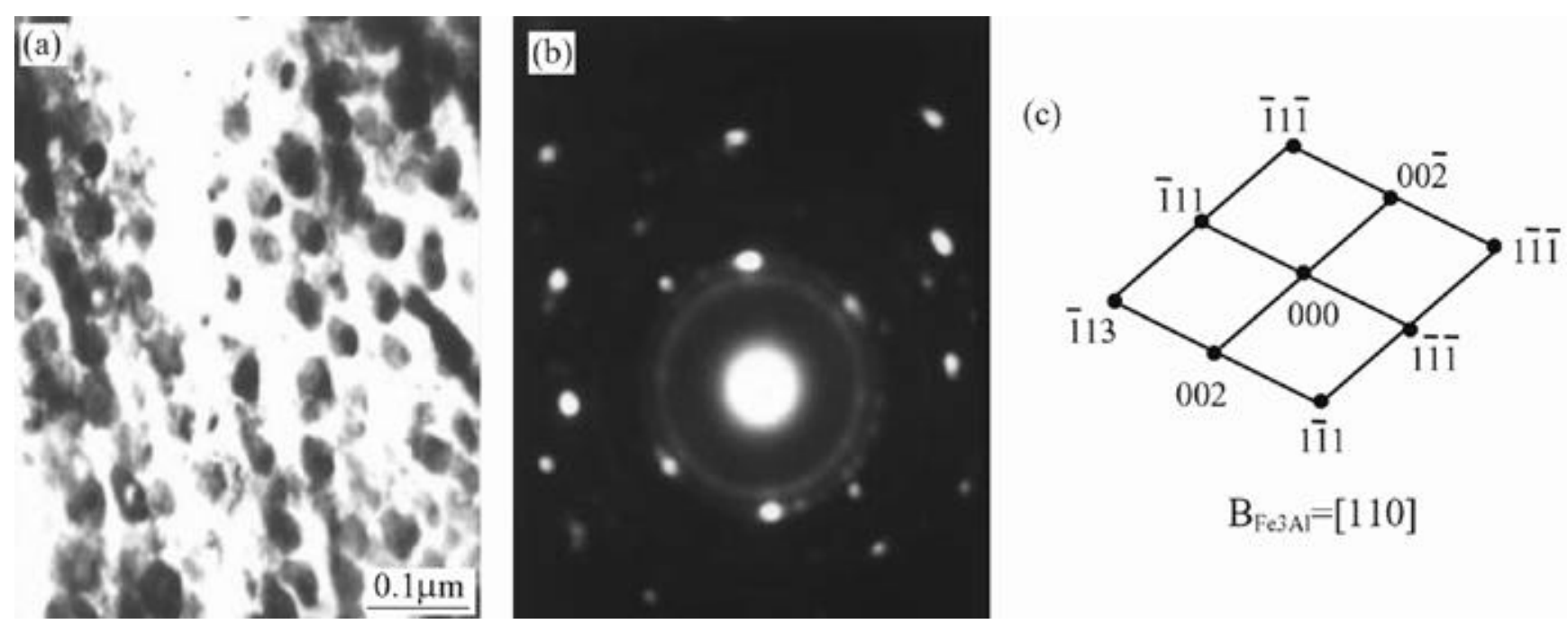

Figure 2. Fine structure of $\mathrm{Fe}_{3} \mathrm{Al}$ in the $\mathrm{Fe}_{3} \mathrm{Al} / \mathrm{Q} 235$ diffusion bonding interface: (a) TEM morphology, (b) electron diffraction pattern and (c) index schematic diagram. 

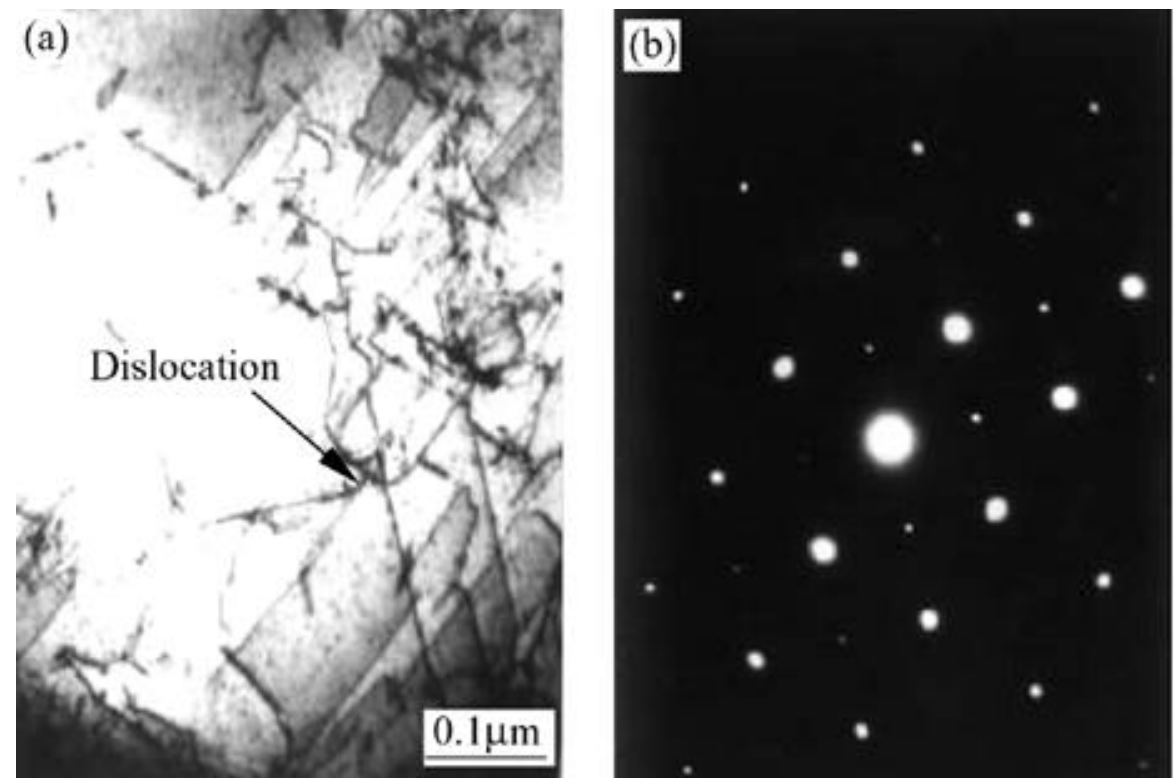

(c)

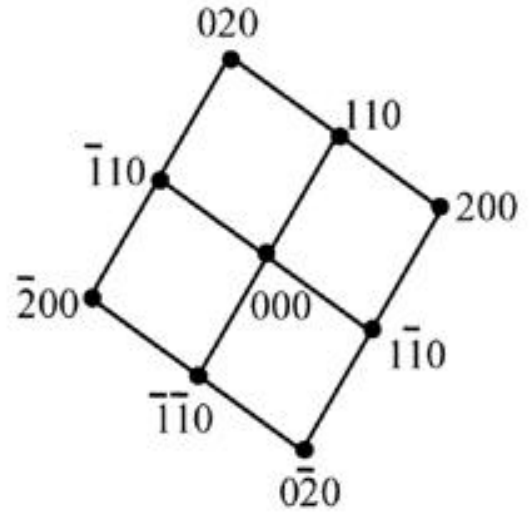

$\mathrm{B}_{\mathrm{Fe} 3 \mathrm{Al}}=[001]$

Figure 3. Fine structure of $\mathrm{Fe}_{3} \mathrm{Al}$ from [001] orientation in the $\mathrm{Fe}_{3} \mathrm{Al} / \mathrm{Cr} 18-\mathrm{Ni} 8$ diffusion bonding interface: (a) TEM morphology, (b) electron diffraction pattern and (c) index schematic diagram.
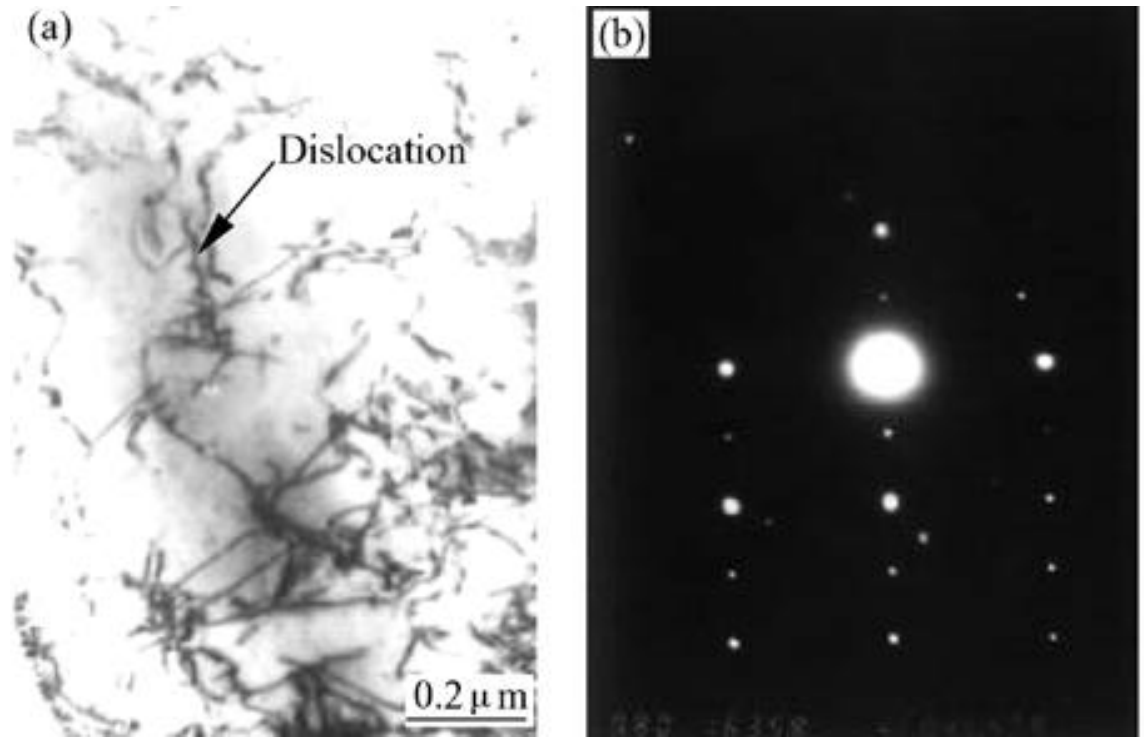

(c)

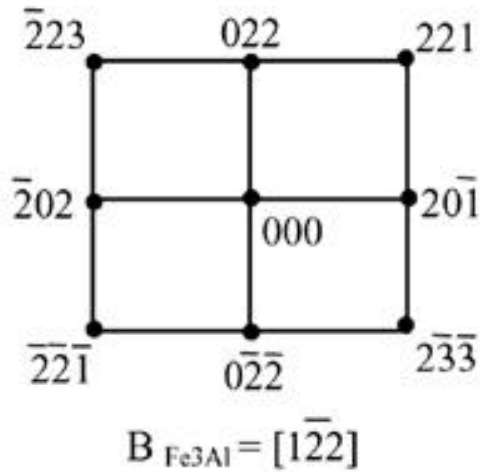

Figure 4. Dislocations in $\mathrm{Fe}_{3} \mathrm{Al}$ from [1ㅡㄹㄹ orientation in the $\mathrm{Fe}_{3} \mathrm{Al} / \mathrm{Cr} 18-\mathrm{Ni} 8$ diffusion bonding interface: (a) TEM morphology, (b) electron diffraction pattern and (c) index schematic diagram.

\section{Conclusions}

The diffusion of $\mathrm{Cr}$ and $\mathrm{Ni}$ at the interface is favourable to improve the strength of the interface between $\mathrm{Fe}_{3} \mathrm{Al}$ and steel. The width of $\mathrm{Fe}_{3} \mathrm{Al} / \mathrm{Cr} 18-\mathrm{Ni} 8$ interface transition zone is $35 \mu \mathrm{m}$. It is larger than that of $\mathrm{Fe}_{3} \mathrm{Al} / \mathrm{Q} 235$ interface transition zone $(29 \mu \mathrm{m})$ under the condition of $1333 \mathrm{~K} \times 60 \mathrm{~min}$ and a pressure of $15 \mathrm{MPa}$. The second phase rich in $\mathrm{Cr}$ and $\mathrm{Ni}$ distributes dispersively in $\mathrm{Fe}_{3} \mathrm{Al}$ formed at the $\mathrm{Fe}_{3} \mathrm{Al} / \mathrm{Cr} 18-\mathrm{Ni} 8$ interface to cause dislocation couples with different spacing and even dislocation network. This is favourable to improve the joint strength at the $\mathrm{Fe}_{3} \mathrm{Al} / \mathrm{Cr} 18-\mathrm{Ni} 8$ interface.

\section{Acknowledgements}

This work was supported by the National Natural Science Foundation of China (Grant No. 50375088) and the Natural Science Foundation of Shandong Province (Grant No. Y2003F05). The authors express their heartfelt thanks for this support. 


\section{References}

David S A and Zacharia T 1993 Weld J. 72201

Gao D C, Yang W Y, Dong M, Huang J H and Sun Z Q 2000 Acta Metall. Sinica 3687

Li Y J and Wang J 2003 J. Mater. Sci. \& Technol. 1981

Mckamey C G, Horton J A and Liu C T 1990 J. Mater. Res. 4 1156
Mckamey C G, Devan J H and Tortorelli P E 1991 J. Mater. Res. 61779

Sun Z Q, Gao D C and Yang W Y 2001 Trans. J. Mater. Res. 1569

Wang J, Li Y J and Wu H Q 2001 Bull. Mater. Sci. 24639

Wang J, Li Y J and Liu P 2003 Int. J. Joining Mater. Sci. 1525

Yin Y S, Fan R H and Xie Y S 1996 Mater. Chem. Phys. 44 190 